\title{
SENSITIVITY ANALYSIS OF THE EFFECT OF INITIAL IMPERFECTIONS ON THE (i) ULTIMATE LOAD AND (ii) FATIGUE BEHAVIOUR OF STEEL PLATE GIRDERS
}

\author{
Zdeněk Kala ${ }^{1}$, Jiř́ Kala ${ }^{2}$, Miroslav Škaloud ${ }^{3}$ and Břetislav Teplý ${ }^{4}$ \\ 1,2 Dept of Structural Mechanics, Brno University of Technology, Faculty of Civil Engineering, \\ Veveři 95, 60200 Brno, Czech Republic.E-mails: kala.z@fce.vutbr.cz; kala.j@fce.vutbr.cz; \\ ${ }^{3}$ Institute of Theoretical and Applied Mechanics, Czech Academy of Sciences \\ Prosecká 76, 19000, Prague 9, Czech Republic. E-mail: skaloud@itam.cas.cz; \\ ${ }^{4}$ Brno University of Technology, Faculty of Civil Engineering, Veveři 95, 66237 Brno, Czech Republic. \\ E-mail: teply@fce.vutbr.cz.
}

Received 16 Dec 2004; accepted 08 Apr 2005

\begin{abstract}
The study is divided into two parts: (i) in the first one, the plate girder (Fig 1) is considered to be exposed to quasi-constant loading (ie to loads which are either constant or repeated in a very small number of cycles), while (ii) in the other one, the girder is assumed to be subjected to repeated loading. Then it is understandable that the objective of the first part should be to look into the influence of initial imperfections on the static ultimate load of the girder related to the formation of a plastic failure mechanism in it, while that of the second part was to study the effect of imperfections on the stress state under considerably lesser loads, viz under such as to correspond to the development of fatigue cracks in the girder and, consequently, to its fatigue limit state. In this case the state of stress was measured by bending stresses developing in the crack-prone areas (Fig 4) of the web "breathing" under the repeated loads, which as demonstrated by the Prague experiments - occur at the toes of the fillet welds connecting the "breathing" web with the girder flanges and stiffeners. In both parts, the results of the theoretical investigation were compared with the conclusions of numerous tests carried out at the Institute of Theoretical and Applied Mechanics in Prague. The correlation was found to be very good; for example, the experimental load-carrying capacity of the girders tested in Prague was close to the mean value of the corresponding theoretical solutions performed for the same girders. Thereby the analytical model applied in the theoretical investigation can be regarded as verified.

The theoretical analysis was based on a non-linear variant of the finite element method, the girder being modelled by means of shell elements and the ANSYS program being applied. All input imperfections were considered to be random quantities. The statistical distributions were introduced according to both experimentally obtained results and data given in literature. Random realisations of input random quantities were simulated by the LHS (Latin Hypercube Sampling) method. By way of sensitivity analysis it was studied to what extend the variability of initial imperfections was reflected in the variability of stresses in the crack-prone areas of the girder.

The main conclusion can be formulated as follows: While the effect of (and sensitivity to) the initial out-of-flatness of the girder web, in the case studied of a plate girder whose web is subjected to predominant shear, on the static load-carrying capacity is (see the results of the first part of the study) very small (only a few p.c.), the same effect on the stress state occurring in the crack-prone areas of the "breathing" web under service loads can be (see the other part of the study) very important. This is also one of the main explanations of the large scatter of the results of the fatigue tests conducted in Prague.
\end{abstract}

Keywords: sensitivity analysis, imperfection, random, steel, structures, fatigue, design, girder.

\section{Introduction}

Thin-walled structures make themselves useful in numerous structural systems, eg, in plains, cars, but also in bridge and technological equipment structures. The slender web is the basic structural element of a thin-walled structure.

The major manifestation of the slender web stability loss is the buckling. In case the structure is stressed by repeated loading, the repeated stability loss of struc- ture slender plate elements causes the repeated state of stress change which is then followed by the fatigue cracks initiation and propagation. First, the stable crack growth occurs at repeated loading. In classical approach, each fatigue process is finished by the brittle fracture. The larger is the stress amplitude in the given point, the rapider occurs the crack propagation. Therefore it is necessary to analyse the factors taking part in the stress variability in the points above all, where the most frequent occurrence of cracks initiation and propagation has 


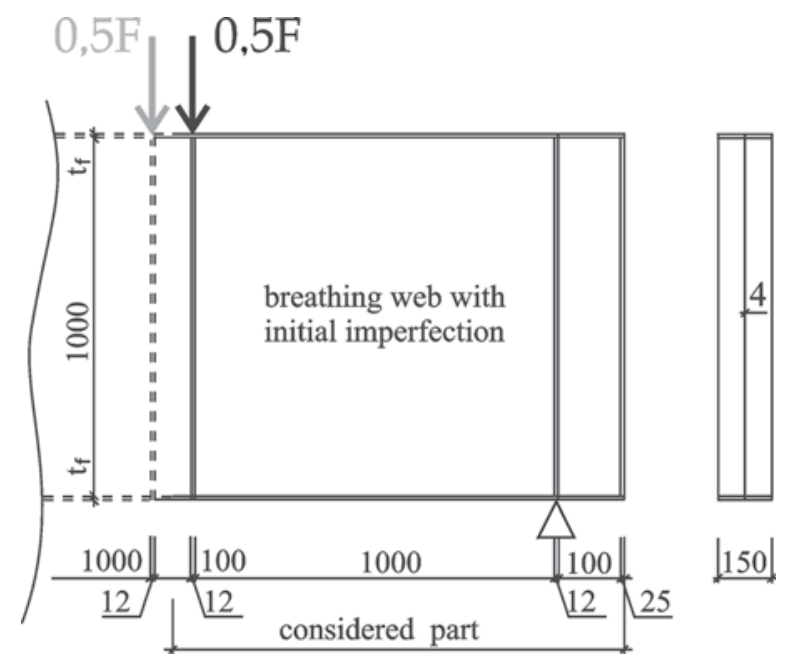

Fig 1. Girder geometry

been confirmed in accordance with experimental results. This topic has been therefore in the focus of interest of numerous research institutes for a certain time - see, eg, papers $[1,2]$ and $[3,4]$.

A correctly designed structure ensures the reliable structure function for its service life. A structure is considered to be reliable when its resistance is higher than the loading effect, namely with satisfactory probability. The resistance of a thin-walled structure is influenced also by initial imperfections. The significance of these imperfections is, however, various, according to the stress type affecting the structure.

The behaviour of thin-walled steel structures at cyclic loading is predestined by the slenderness of individual plates. Insufficient knowledge of stability problems often leads in design practice to uneconomic structures. The design of a thin-walled system is always more complicated because it is necessary to take into account the influence of initial imperfections to a larger extent, as well. On behalf of the so-called stochastic sensitivity analysis $[5,6]$, it can be distinguished what is the influence of individual imperfections. This paper deals with the comparison of results following from both experimental and theoretical analyses of the thin-walled structure resistance, and refers to the dominance of some imperfections.

\section{Sensitivity analysis}

The stochastic sensitivity analysis enabled us to assess the relative sensitivity of random variability of the phenomenon studied to the random variability of individual input quantities $[5,6]$. Of course, it would be preferable to carry out a sensitivity analysis based on experimental results obtained, but this is practically impossible - particularly from the economic point of view. Furthermore, only some characteristics can be measured by non-destructive methods at least in a reliable way.
Considering the large heterogeneity of initial imperfections and the possibility of their complex interaction, it is more advantageous to apply the so-called numerical sensitivity analysis (taking into account some results of the experimental. In so doing, we can profit from research carried out in Prague, with the cooperation of research teams in Cardiff, Liège and Stuttgart; see, for example, [1, 2]).

In the first studies, the methods of deterministic sensitivity analysis were applied [4]. A similar problem - utilising the deterministic sensitivity analysis - was studied by Rangelov [7] too. This analysis is a method sometimes applied in the design of structures, where it usually accompanies the design process in which a computer model is used. Such an analysis thus consists of a sequence of calculations with a gradually changing, in each calculation run $j(j=1,2, \ldots, k)$, value of the input parameters $X_{\mathrm{i}}$ studied, and this in a certain real extent. By comparison of calculation results of $Y_{\mathrm{j}}$ ( $K$ values of structure response), the influence of parameter $X_{i}$ on the response of $Y_{\mathrm{j}}$. can be evaluated. So, if applying the deterministic sensitivity analysis, we deliberately disregard valuable information about the variability of the input data.

The objective of this paper is therefore a stochastic sensitivity analysis which provides more extended information about the problem studied. The random input quantities are considered as if they were obtained by measurements, this enabling us to get a quantified information about the influence of the scatter of individual parameters involved. This procedure can be with advantage employed in connection with the numerical simulation method Latin Hypercube Sampling Method (LHS), such as suggested in the review paper by [5], where also other variants of the stochastic sensitivity analysis are described. The LHS method is a method of the Monte Carlo type, which makes it possible to simulate the realisations of input random quantities as if they were obtained by measurements. In the present paper, the sensitivity analysis is evaluated in the form of Spearman rank-order correlation coefficient:

$$
r_{s, i}=1-\frac{6 \sum_{j=1}^{N}\left(q_{j, i}-p_{j}\right)^{2}}{N^{3}-N}, \quad r_{s, i} \in[-1,1]
$$

where $r_{\mathrm{s}, \mathrm{j}}$ is the order representing the value of random variable $X_{\mathrm{i}}$ in an ordered sample among $N$ simulated values applied in the $j_{\text {th }}$ simulation (the order $q_{\mathrm{i}}$ equals the permutation at LHS), $p_{\mathrm{j}}$ is the order of an ordered sample of the resulting variable for the $j_{\text {th }}$ run of the simulation process.

The method is based on the assumption that the random quantity influencing (both positively and negatively) the output quantity change significantly will have a higher correlation coefficient. Opposite to this, the coefficient with its value near to zero will signalise a low influence. Let us note that the sensitivity coefficients 
provide information on the relative influence of the input random quantities change on the output quantity change (eg, on the stress state).

\section{The initial random parameters}

In the stochastic sensitivity analysis of steel girders resistance, it is necessary to assess statistical characteristics of real mechanical characteristics of steels. Mechanical characteristics of plates - yield strength, strength and ductility - were measured experimentally [8] (in compliance with the standard $[9,10])$. An example of statistical distribution of yield strength in 5493 tensile coupons of plates in S235 steel grade is illustrated by the histogram in Fig 2.

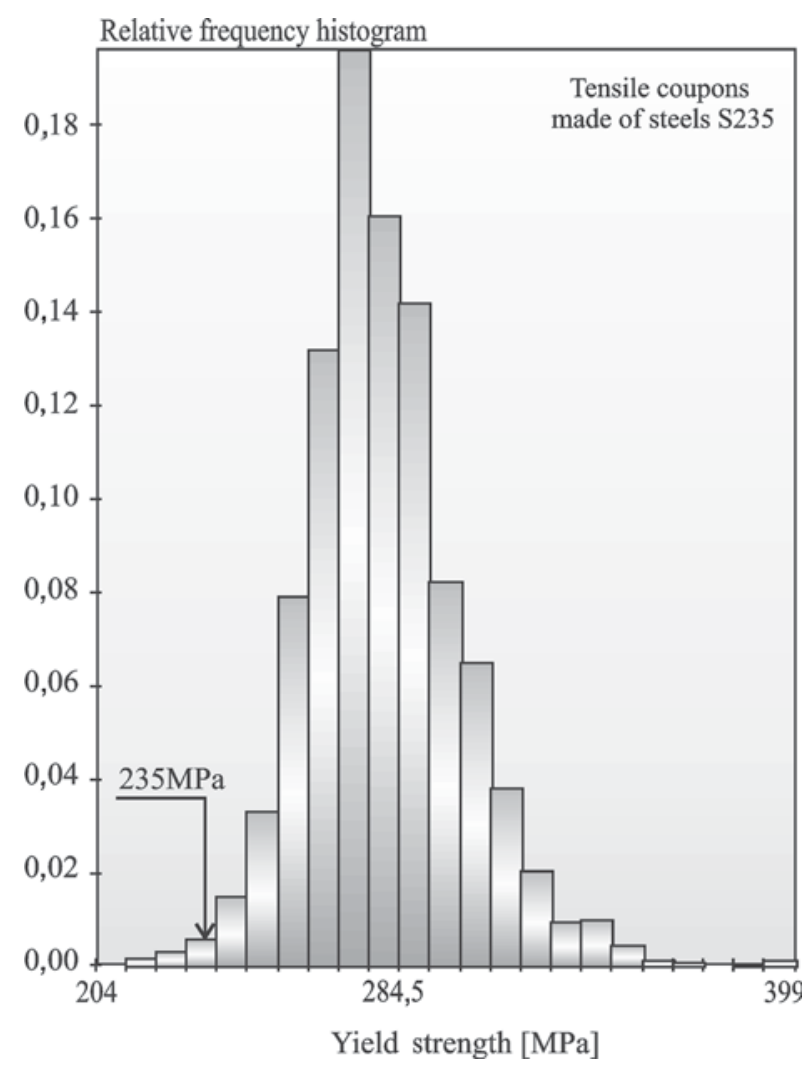

Fig 2. Histogram of the yield strength of tensile coupons

For the not measured quantities (eg, Young's modulus), it was issued, in the presented study, from the data given in the literature. According to two independent experimental results $[11,12]$, the Young's modulus $E$ was considered to be a random quantity with mean value $m_{\mathrm{E}}=210 \mathrm{GPa}$ and standard deviation $S_{\mathrm{E}}=12,6 \mathrm{GPa}$. An ideally elastic-plastic material was considered.

The variation coefficient of web thickness was considered here, according to experience, by the value 0,07 . The influence of residual stress was neglected in the present study.

The initial out-of-plane imperfection was considered in the shape of one half-wave of the sine function with variable maximum amplitude (Fig 8). The mean value
Input random quantities

\begin{tabular}{|c|c|c|c|c|c|}
\hline No & $\begin{array}{l}\text { Name of random } \\
\text { quantity }\end{array}$ & $\begin{array}{c}\text { Type of } \\
\text { distribu- } \\
\text { tion }\end{array}$ & $\begin{array}{c}\text { Dimen- } \\
\text { sion }\end{array}$ & Mean & $\begin{array}{l}\text { Standard } \\
\text { deviation }\end{array}$ \\
\hline 1. & $\begin{array}{l}\text { Amplitude of sine } \\
\text { initial web curvature }\end{array}$ & $* * * *$ & $\mathrm{~mm}$ & 3,575 & 3,336 \\
\hline 2. & Web thickness & * & $\mathrm{mm}$ & 4 & 0,2 \\
\hline 3. & Web yield strength & ** & $\mathrm{MPa}$ & 284,5 & 21,5 \\
\hline 4. & $\begin{array}{l}\text { Web Young's } \\
\text { modulus }\end{array}$ & $*$ & GPa & 210 & 12,6 \\
\hline 5. & $\begin{array}{l}\text { Thickness of upper } \\
\text { flange }\end{array}$ & * & $\mathrm{mm}$ & 10 & 0,7 \\
\hline 6. & $\begin{array}{l}\text { Yield strength of } \\
\text { upper flange }\end{array}$ & $* *$ & $\mathrm{MPa}$ & 284,5 & 21,5 \\
\hline 7. & $\begin{array}{l}\text { Young's modulus of } \\
\text { upper flange }\end{array}$ & * & GPa & 210 & 12,6 \\
\hline 8. & $\begin{array}{l}\text { Thickness of lower } \\
\text { flange } \\
\end{array}$ & * & $\mathrm{mm}$ & 10 & 0,7 \\
\hline 9. & $\begin{array}{l}\text { Yicld strength of } \\
\text { lower flange }\end{array}$ & $* *$ & $\mathrm{MPa}$ & 284,5 & 21,5 \\
\hline 10. & \begin{tabular}{|l|}
$\begin{array}{l}\text { Young's modulus of } \\
\text { lower flange }\end{array}$ \\
\end{tabular} & * & $\mathrm{GPa}$ & 210 & 12,6 \\
\hline 11. & $\begin{array}{l}\text { Thickness of left- } \\
\text { hand stiffener }\end{array}$ & * & $\mathrm{mm}$ & 12 & 0,84 \\
\hline 12. & $\begin{array}{l}\text { Yield strength of left- } \\
\text { hand stiffener }\end{array}$ & $* *$ & $\mathrm{MPa}$ & 284,5 & 21,5 \\
\hline 13. & $\begin{array}{l}\text { Young's modulus of } \\
\text { left-hand stiffener }\end{array}$ & * & $\mathrm{GPa}$ & 210 & 12,6 \\
\hline 14. & $\begin{array}{l}\text { Thickness of central } \\
\text { stiffener }\end{array}$ & * & $\mathrm{mm}$ & 12 & 0,84 \\
\hline 15. & $\begin{array}{l}\text { Yield strength of } \\
\text { central stiffener }\end{array}$ & $* *$ & $\mathrm{MPa}$ & 284,5 & 21,5 \\
\hline 16. & $\begin{array}{l}\text { Young's modulus of } \\
\text { central stiffener }\end{array}$ & $* *$ & $\mathrm{GPa}$ & 210 & 12,6 \\
\hline 17. & $\begin{array}{l}\text { Thickness of right- } \\
\text { hand stiffener }\end{array}$ & * & $\mathrm{mm}$ & 12 & 0,84 \\
\hline 18. & $\begin{array}{l}\begin{array}{l}\text { Yield strength of } \\
\text { right-hand stiffener }\end{array} \\
\end{array}$ & $* *$ & $\mathrm{MPa}$ & 284,5 & 21,5 \\
\hline 19. & $\begin{array}{l}\text { Young's modulus of } \\
\text { right-hand stiff }\end{array}$ & $*$ & $\mathrm{GPa}$ & 210 & 12,6 \\
\hline
\end{tabular}

*Gauss, ** Histogram, *** Rectangular, **** Lognormal

$3,575 \mathrm{~mm}$ and the standard deviation $3,336 \mathrm{~mm}$ of the lognormal distribution (Table) of the sine function amplitude were determined according to experimental results [13]. It has been confirmed by the Chi-square test that the lognormal distribution function can be assumed for the measured quantities.

The results of initial curvature measurements in preselected mesh nodes were approximated by the double Fourier series with 9 summands (one, two and three half-waves of the sine function both in vertical and horizontal directions). The initial curvature was statistically evaluated for 16 girder webs. The highest values were found for the first summand of the Fourier series (shape $1 \times 1$ ). The conclusions presented enable us to introduce, in the stochastic model, the shape of the web initial curvature in the form of one half-wave of the sine function both in vertical and hori- 
zontal directions. The results of experimental research and the description of the experiment are given in detail in [13].

An outline of input random quantities is given in Table. The statistical independence was supposed for all the input random quantities. The loading was considered, for the purposes of the present study, to be deterministic.

The characteristics given in Table were applied in the LHS simulations; it leads thus to obtaining the statistical moments, eg states of stress in the followed points, and to the possibility of calculating and evaluating the Spearman rank-order coefficients (1). Such points in which it is interesting to determine the stress sensitivity were determined, based on experimental research - see below.

\section{Experimental results}

The influence of repeated loading on fatigue cracks initiation and propagation is being under experimental research at the Institute of Theoretical and Applied Mechanics in Prague. The girder examined with geometry according to Fig 1 is presented in Fig 3. The load-bearing capacity of the girder mentioned was determined, by the ultimate loading test, to have the value of $700 \mathrm{kN}$.

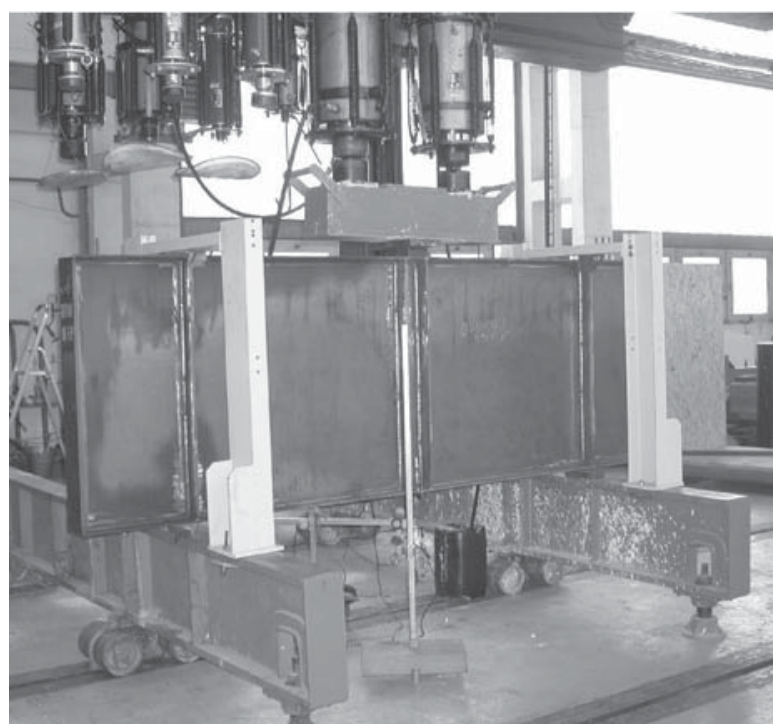

Fig 3. Experimental results of the girder under compression (Prague 2003)

It has become evident that, most frequently, the initiation of fatigue cracks occurs in the neighbourhood of fillet welds close to the web tension band. The points in which, according to the experimental results, fatigue cracks initiate most probably, are marked "under a magnifying glass" in Fig 4. The illustrations of fatigue cracks details are presented in Figs 5, 6 and 7.

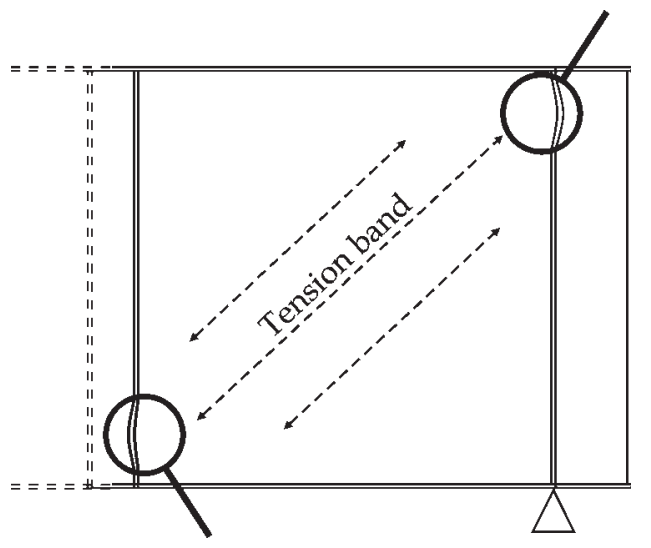

Fig 4. Tension band illustration

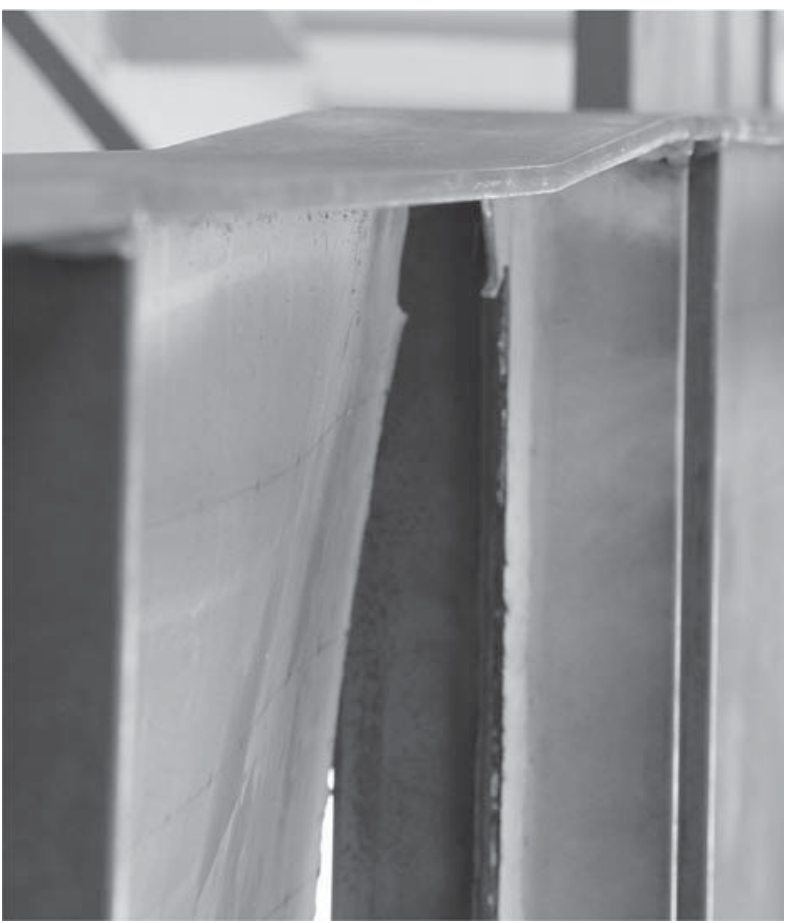

Fig 5. Fatigue crack detail

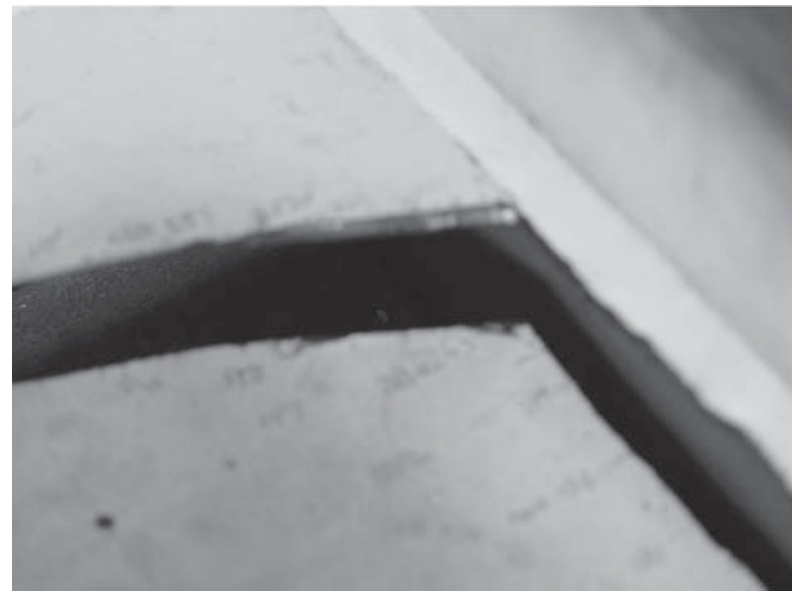

Fig 6. Fatigue crack detail 


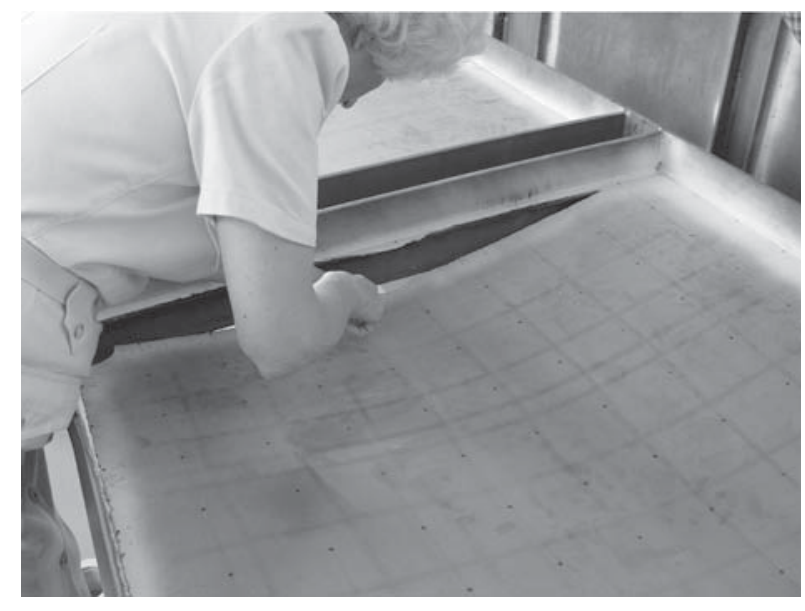

Fig 7. Fatigue crack detail

\section{Numerical analysis}

The girder presented in Fig 1 was modelled by the finite element method, applying the ANSYS programme. Rather a fine mesh of shell elements SHELL 181 was used (Fig 8). The symmetry of girder and loading was exhausted. For steel grade S235, bilinear cinematic material hardening was supposed. Further on, it was assumed that the onset of plastification occurred when the von Mises equivalent stress exceeded the yield stress.

Within the framework of each run of the LHS method, the stress-strain state was found out by the geometrically and materially non-linear FEM solution. The Euler method based on proportional loading in combination with the Newton-Raphson method was used.

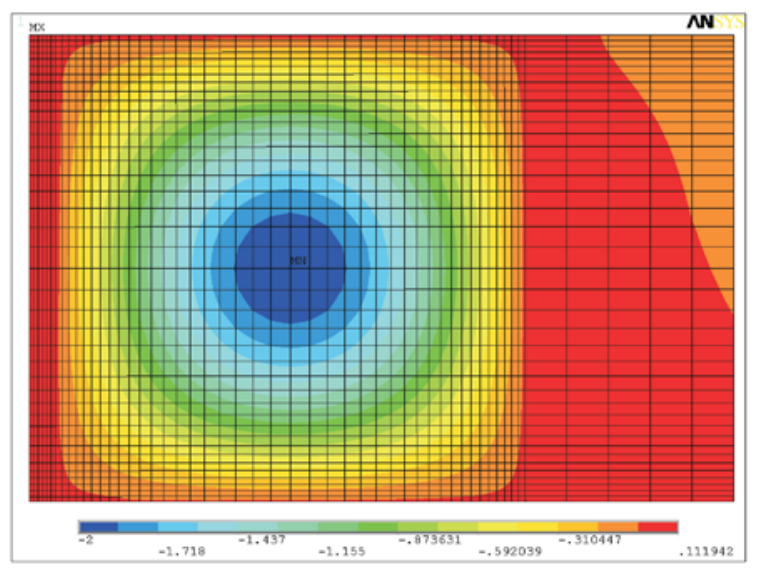

Fig 8. Finite element model with initial out-of-plane imperfection

\section{Statistical and sensitivity analysis of the girder load- bearing capacity}

Realisations (simulations) of random load-bearing capacity determined by a non-linear calculation on behalf of the programme ANSYS are presented in Fig 11.

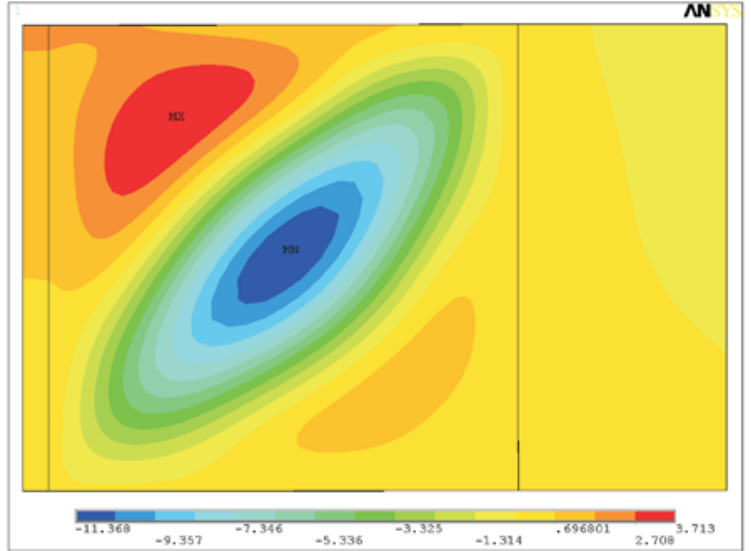

Fig 9. Girder out-of-plane displacement loaded by $50 \%$ bearing capacity

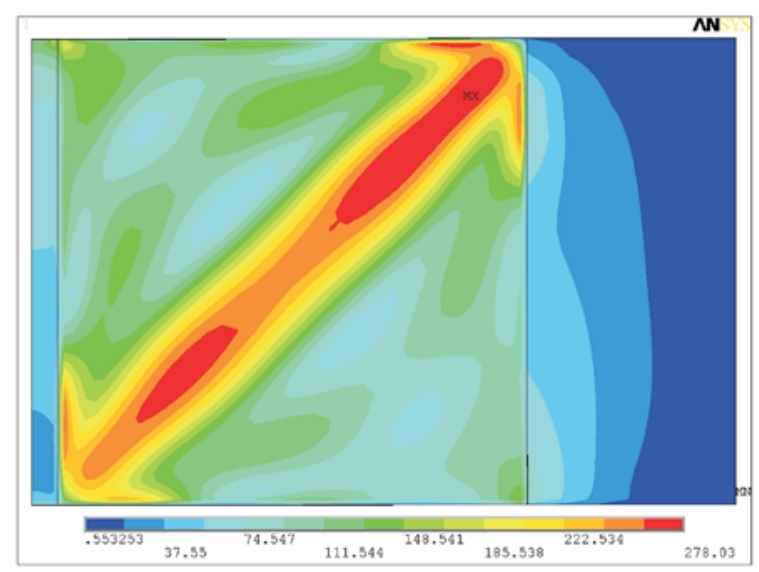

Fig 10a. Mises equivalent stress on top shell surface

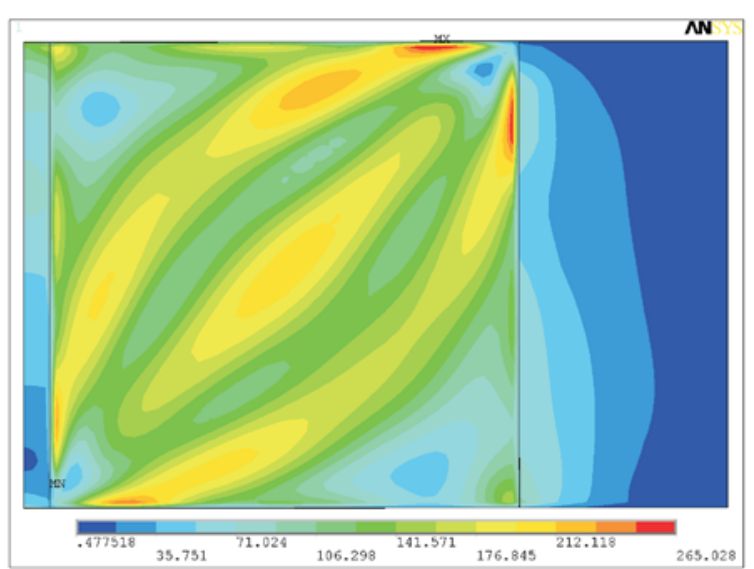

Fig 10b. Mises equivalent stress on bottom shell surface

The load-bearing capacity was determined as the loading rate at which the matrix of tangential toughness determinant $K_{t}$ of the structure approaches zero with accuracy of $0,1 \%$. The load-bearing capacity determined experimentally is in good agreement with the mean value determined by theoretical solution [5]. 


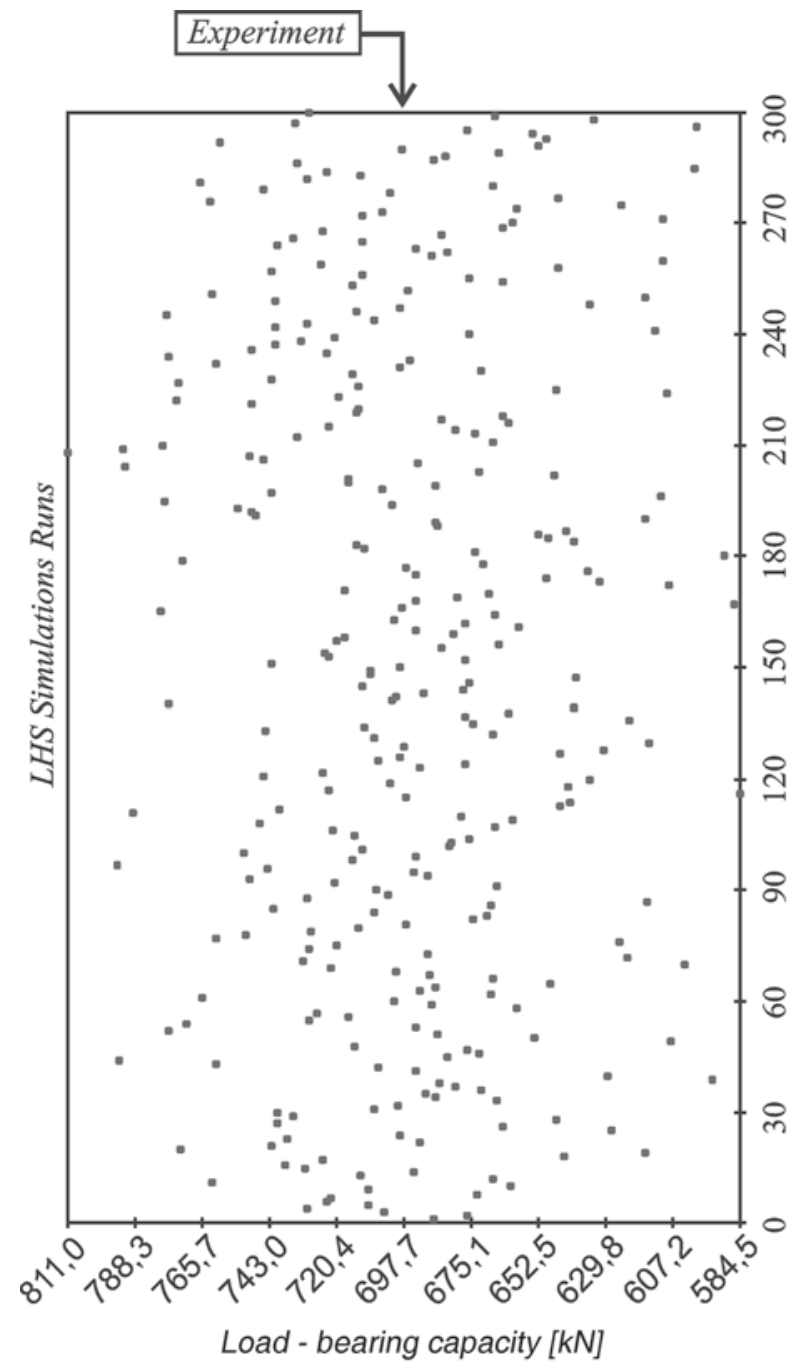

Fig 11. Valid observations of load-bearing capacity

The mean value of the load-bearing capacity is $m_{\mathrm{F}}=696,51 \mathrm{kN}$; standard deviation is $S_{\mathrm{F}}=44,577 \mathrm{kN}$.

Fig 12 gives the results of an analysis of the sensitivity of the load-bearing capacity to initial imperfections. As long as the value of the correlation coefficient increases, the load-bearing capacity increases when also the value of the input quantity grows. A negative value of the coefficient refers to the negative effect of the quantity on the load-bearing capacity (eg the quantity No 1 numbering of variables see Table).

\section{Sensitivity analysis of stress state under the work- ing load}

In Fig 13 there are marked the points in which the initiation and propagation of fatigue cracks occurred frequently both at experimental study and in real structures. Therefore the stress in points A, B, chosen close to the tension band was analysed by means of theoretical analysis (Fig 4).

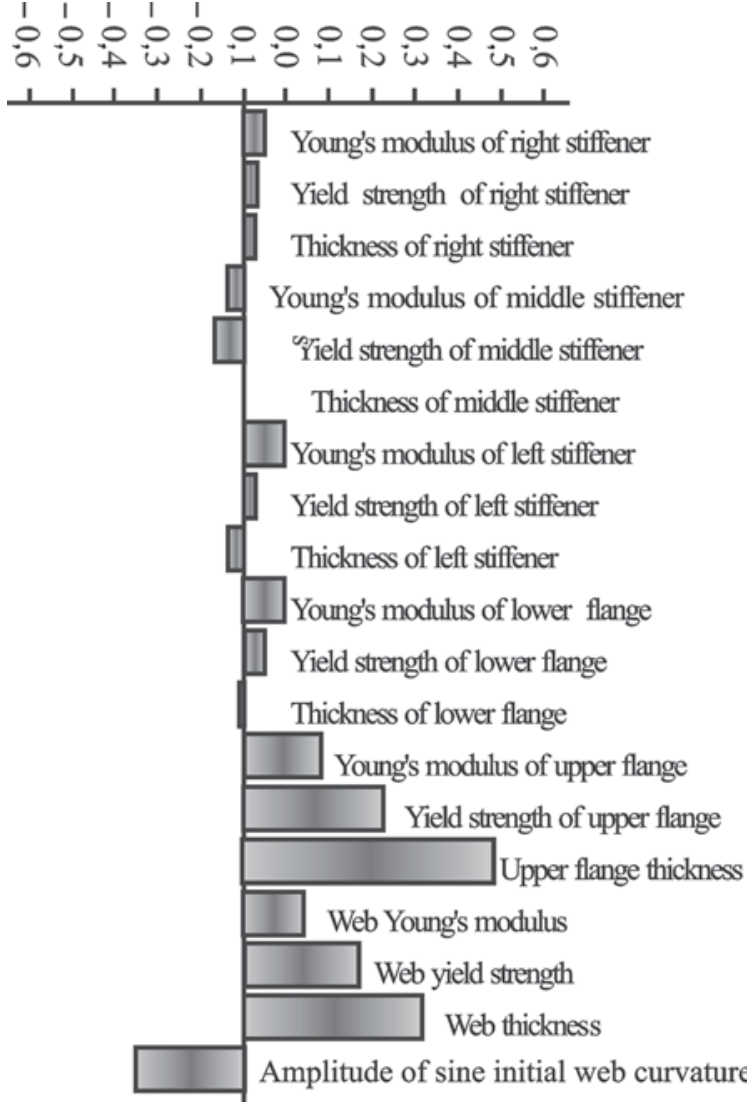

Fig 12. Sensitivity analysis of the load-bearing capacity

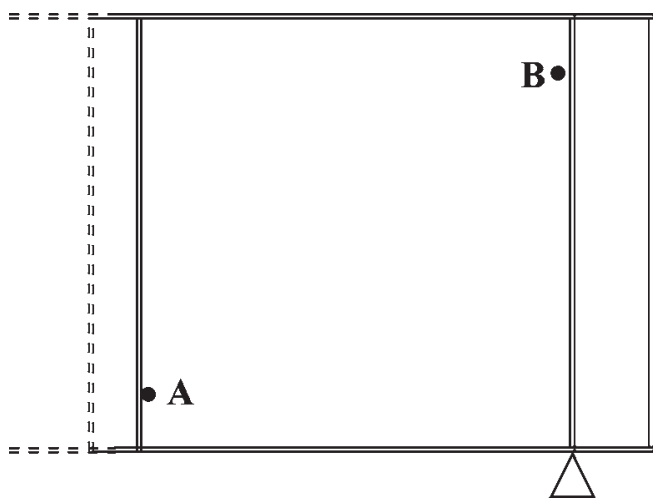

Fig 13. Points of analysed bending stress

As the aim of our study is to serve mainly for obtaining knowledge connected with fatigue failure, in the following part of the study, the bending stress of girder loaded by the forces $F=70 \mathrm{kN}$ and $F=350 \mathrm{kN}$ was analysed. This loading value corresponds to $10 \%$ and $50 \%$ of load-bearing capacity determined experimentally. The stress perpendicular to web circumference was determined by non-linear calculation in a similar way as when calculating the load-bearing capacity by the FEM model.

In Figs 14 to 17 there are given the sensitivity analysis results of the influence of input imperfections vari- 


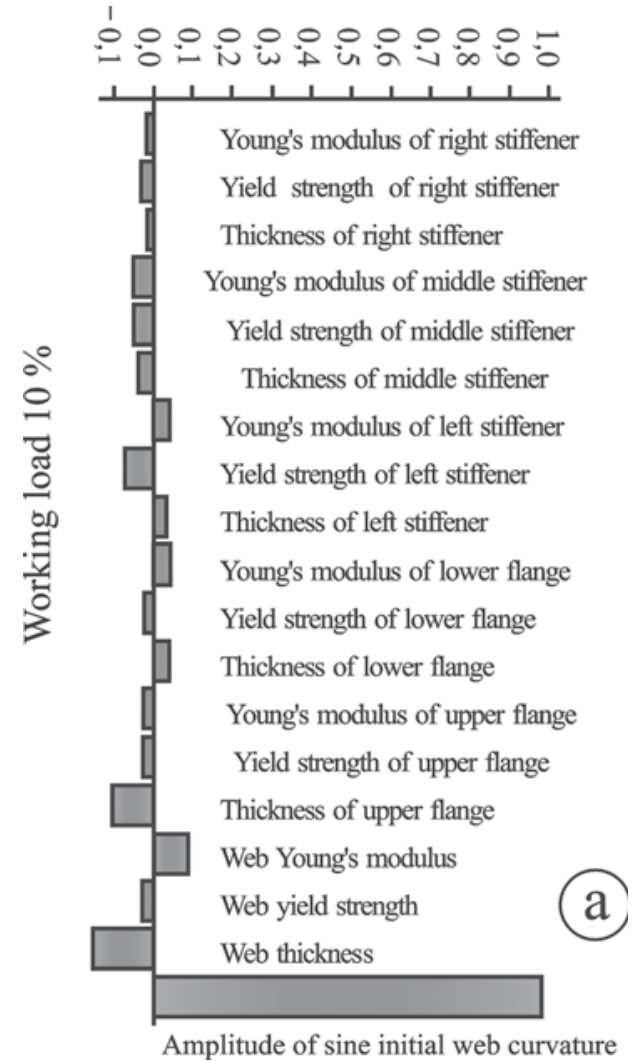

Fig 14. Sensitivity analysis of bending stress in point A

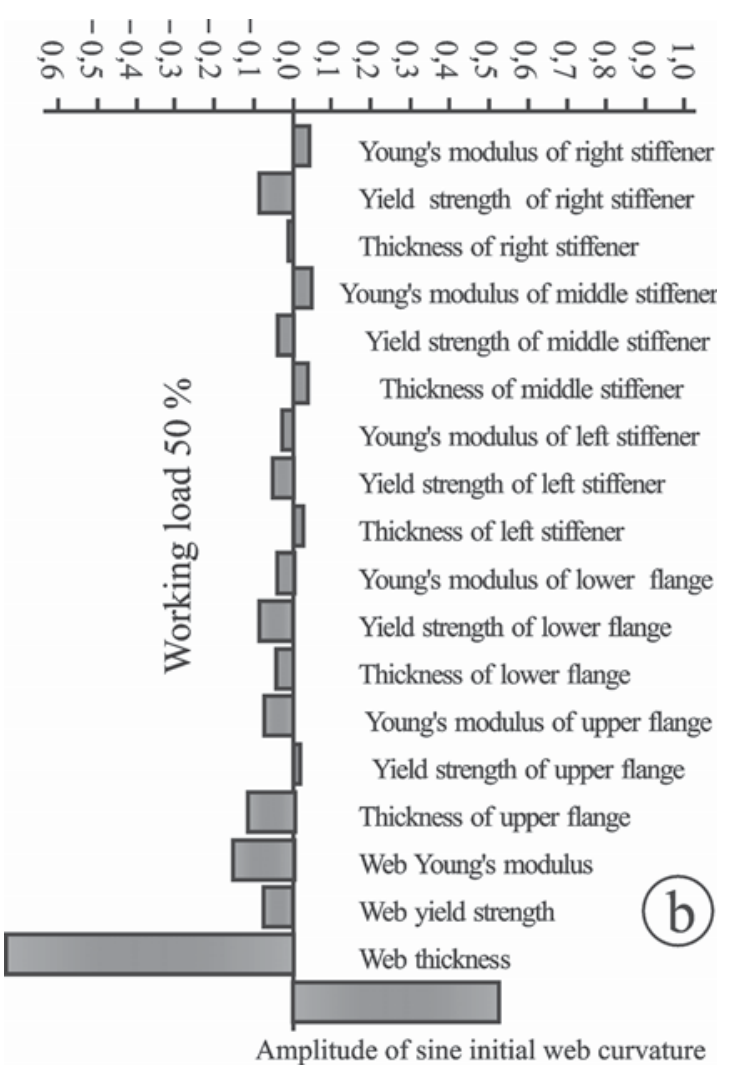

Fig 15. Sensitivity analysis of bending stress in point A

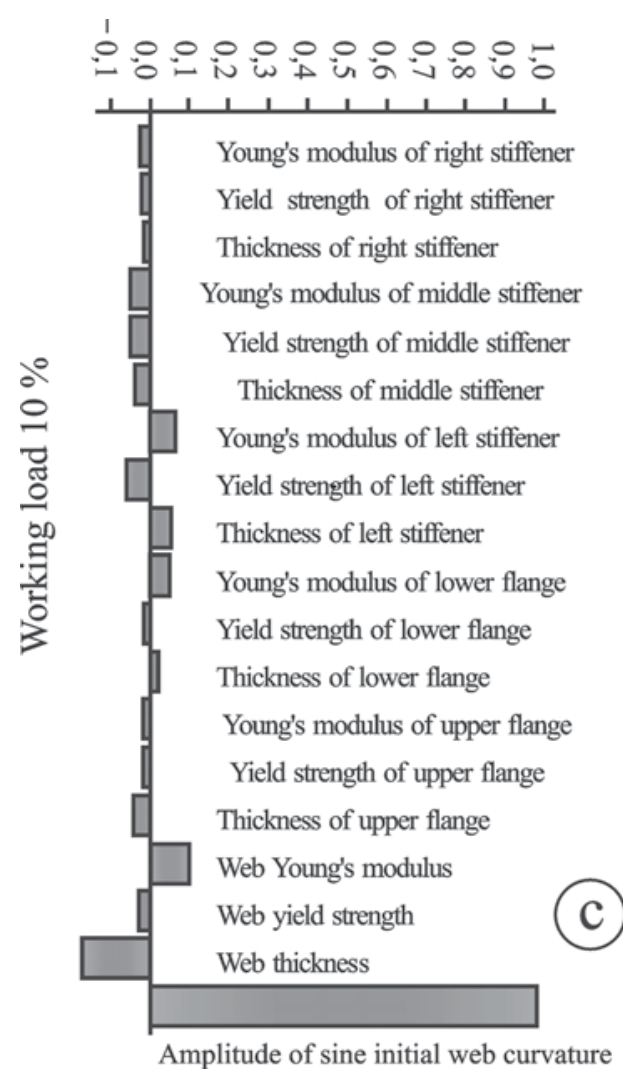

Fig 16. Sensitivity analysis of bending stress in point B

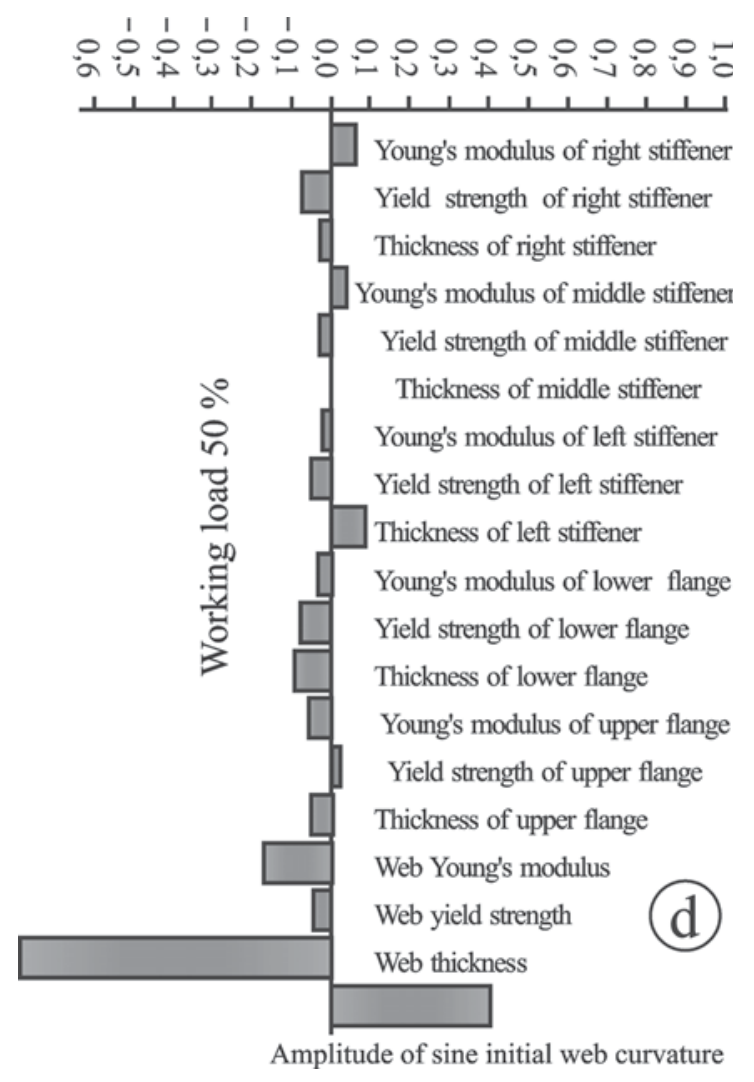

Fig 17. Sensitivity analysis of bending stress in point $B$ 
ability on the bending stress variability in points A, B at the loading close to working load. With regard to the numerical methods applied, also the values of sensitivity coefficients obtained are burdened by a certain error. In quantities with lower sensitivity coefficients, a relatively higher number of simulation coefficients would be needed for a more accurate determination of their values.

\section{Conclusion}

It has been found by the sensitivity analysis that the girder thickness of web, thickness of upper flange also yield strength of upper flange influence the load-bearing capacity in the dominant manner (Fig 1). The positive value of the correlation coefficient means that if the value of these quantities increases, the load-bearing capacity increases as well. The variability of quantities mentioned influence the variability of the load-bearing capacity rather significantly. The influence (negative) of initial curvature on the girder load-bearing capacity is relatively low; the results of studies [11] confirm this as well.

For the behaviour analysis of a structure under current working load, it is relevant to observe the stress near filled welds in the points in which, according to the experimental results, crack initiation and propagation take place most frequently (Figs 4, 13). The stress sensitivity analysis was carried out for load equalling 10 and $50 \%$ of average load-bearing capacity; this is the interval in which the working load occurs with a high frequency. A significant influence of the slender web initial curvature on the variability of bending stress in the points followed was found for the load value $10 \%$ (Figs 14, 16). For the value $50 \%$, the variability of bending stress is influenced, to a maximum extent, by the web thickness together with the slender web initial curvature (Figs 15, 17).

This knowledge is important in the fatigue limit state analysis, above all, when the initiation and propagation of cracks are limited, in particular by state of stress (cyclic loading) changing in time.

\section{Acknowledgements}

The paper was elaborated under the research projects No 103/03/0233 and Research centre project Reg No 1 M6840770001 and also within the research project No 103/05/2059.

\section{References}

1. Roberts, T. M.; Davies, A. W. Fatigue Induced by Plate Breathing. Journal of Constructional Steel Research, 2002, p. $1495-1508$.

2. Maquoi, R.; Škaloud, M. Some Remarks in Regard to the Fatigue Analysis of Steel Plate Girders with Breathing Webs. In: Proc. of 20th Czech and Slovak Conference "Steel Structures and Bridges", Prague, 2003, p. 397-402, ISBN 80-01-02747-3.

3. Ravinger, J.; Psotn ý, M. Stable and Unstable paths in the Post-Buckling Behaviour of Slender Web, In Proc. of the Fourth International Conference on Coupled Instabilities in Metal Structures, Rome (Italy) 2004, p. 67-75.

4. Kala, Z.; Kala, J.; Škaloud, M., and Teplý, B. Analysis of the Effect of Initial Curvature on the Stress State in Breathing Webs. In: Proc. of International Colloquium, Budapest, 2002, p. 425-432, ISBN 9630579502.

5. Novák, D., Teplý, B., and Shiraishi, N. Sensitivity Analysis of Structures - a Review. In: Proc. of The Fifth International Conference on Civil and Structural Engineering Computing, Edinburgh, Scotland, 1993, p. 201-207.

6. Kala, Z. Sensitivity Analysis of the Stability Problems of Thin-walled Structures. Journal of Constructional Steel Research 61 (2005), p. 415-422, ISSN 0143-974X.

7. Rangelov, N. Influence of Web Imperfections in Welded I-beams with Slender Webs. In: Proceedings of SDSS'99 (edit. D. Dubina and M. Iványi), 1999, Elsevier Science Ltd., p. 175-182.

8. Melcher, J.; Kala, Z.; Holický, M.; Fajkus, M. and Rozlívka, L. Design Characteristics of Structural Steels Based on Statistical Analysis of Metallurgical Products. Journal of Constructional Steel Research, 60 (2004), p. 795-808, ISSN 0143-974X.

9. ČSN EN 10025 A1- Výrobky Válcované za tepla z nelegovaných konstrukčních ocelí (The Hot-Rolled Beam From Structural Steel), 1996.

10. ČSN EN 10002-1 -Zkouška tahem (Experiments in Tension).

11. Fukumoto, Y.; Kajita, N. and Aoki, T. Evaluation of Column Curves Based on Probabilistic Concept. In: Proc. of Int. Conference on Stability, Prelim. Rep., publ. by Gakujutsu Bunken Fukyu - Kai, Tokyo, 1976, p. 1-37.

12. Guedes Soares, C. Uncertainty Modelling in Plate Buckling. Structural Safety (5), 1988, p. 17-34.

13. Kala, Z.; Kala, J.; Škaloud, M., and Teplý. The Stress State in the Crack-Prone Areas of „Breathing“ Thin Walled Girders - a Sensitivity Analysis. In: Proc. of the Fourth International Conference on Coupled Instabilities in Metal Structures, Rome (Italy) 2004, p. 265-276. 


\section{PRADINIŲ TRŪKUMŲ ITTAKOS PLIENINIŲ SUDĖTINIŲ SIJŲ (i) KRITINEI APKROVAI IR (ii) NUOVARGIO BŪVIUI JAUTRUMO ANALIŻं}

\section{Z. Kala, J. Kala, M. Škaloud and B. Teplý}

Santrauka

Tyrimas yra padalytas i dvi dalis: (i) pirmojoje laikoma, kad sudètinė sija (1 pav.) yra veikiama pastovaus apkrovimo (t. y. apkrovų, kurios pastovios arba kartotinès, tačiau esant labai mažam ciklų skaičiui), (ii) antrojoje dalyje laikoma, kad sija yra veikiama daugkartinių kartotinių apkrovų. Pirmojoje dalyje nagrinejjama pradinių trūkumų įtaka sijos statinei kritinei apkrovai, kai susidaro jos plastinio irimo mechanizmas, antrojoje dalyje nagrinejama trūkumu itaka itempių būviui, kai veikia daug mažesnès apkrovos, kai susidaro sijos nuovargio plyšiai ir jos nuovargio ribinis būvis. Šiuo atveju įtempių būvis buvo išmatuotas pagal lenkiamuosius įtempius, atsiradusius dèl kartotinių apkrovų sukelto sienelès „kvejpavimo“ " plyšių išsivystymo (4 pav.), kurie, kaip parodė Prahoje atlikti bandymai, atsiranda apvadinių siūlių jungiančių „kvėpuojančią" sienelę su sijos juostomis ir standumo elementais, apačioje. Tyrimų rezultatai buvo palyginti su daugkartinių bandymų, atliktų Prahos teorinès ir taikomosios mechanikos institute, išvadomis. Buvo nustatyta aiški koreliacija: sijų eksperimentiné laikomoji galia buvo artima atitinkamų teorinių sprendinių vidutinèms reikšmėms. Todẻl analizinis modelis, naudotas teoriniam tyrimui, gali būti laikomas patikimu.

Teorinè analizè buvo pagrissta netiesiniu baigtinių elementų metodo variantu, kai sija buvo sumodeliuota kevaliniais elementais ir buvo naudojama ANSYS programa. Visi trūkumai buvo vertinti kaip atsitiktiniai dydžiai. Statistiniai pasiskirstymai buvo imti remiantis bandymų rezultatais ir literatūros duomenimis. Itrauktų atsitiktinių dydžiu atsitiktiniai pasiskirstymai buvo modeliuoti LHS (Latin Hypercube Sampling) metodu. Jautrumo analizès būdu buvo nagrinèta, kur išplinta pradinių trūkumų kintamumas, kuris atspindi sijos plyšių išsivystymo plotelių ịtempių kintamumą.

Svarbiausia išvada: nors sijos sienelès pradinio išsikreivinimo įtaka ir jautrumas tuo atveju, kai buvo nagrinèta sudètinė sija, kurios sienele yra veikiama vyraujančios šlyties, statinei laikomajai galiai yra labai maža (žr. tyrimo pirmosios dalies rezultatus) (tik keli procentai), ta pati ittaka įtempių būviui, atsirandančiam „kvèpuojančios“ sienelès plyšių išsivystymo ploteliuose, kai veikia eksploatacinès apkrovos, gali būti labai svarbi (žr. antrają tyrimų dali). Tai vienas iš pagrindinių atsakymų, kodèl nuovargio bandymų, atliktų Prahoje, rezultatų sklaida buvo didelè.

Raktažodžiai: jautrumo analizè, yda, plienas, konstrukcijos, nuovargis, projektavimas, sija.

Zdenek KALA. Lecturer at Associate Professor's position, Dept of Structural Mechanics, Faculty of Civil Engineering, Brno University of Technology, Czech Republic. His research interests include structural safety and reliability, stability problems of structures, FEM - non-linear behaviour of thin-walled structures and fuzzy sets theory.

Jiri KALA. Senior Lecturer at Dept of Structural Mechanics, Brno University of Technology, Faculty of Civil Engineering. His research interest is a wide range of numerical simulations based on FEM - thin-walled structures, dynamically loaded systems, fluid-structure interaction, CFD.

Bretislav TEPLY. Professor at the Faculty of Civil Engineering, Brno University of Technology. Member of CIB W80/ RILEM TC140 "Life time Methodologies", Czech National Technical Committee for Structural Reliability, member of Engineering Academy of the Czech Republic. His research interests include structural safety and reliability, structural life-time prediction and risk assessment.

Miroslav SKALOUD. Chief scientific officer at the Institute of Theoretical and Applied Mechanics, Czech Academy of Sciences. Lecturer at Professor's position at 3 technical universities in the Czech Republic and 23 universities abroad. His research interests include stability problems of structures, analysis of plated structures, and analysis of thin-walled systems, plastic design of steel structures and fatigue of structures 